\title{
Host-Parasite Relationship in Gastrointestinal Helminthiasis
}

\author{
Pierre Pery \\ Station de Recherches de Virologie et d'Immunologie, INRA, Thiverval-Grignon, France
}

Gastrointestinal helminths are extremely numerous both in man and in animals where they cause severe impaired production. The deleterious effects of an infection is easily demonstrated with blood-sucking parasites: the daily loss of blood in sheep infected with Haemonchus contortus can exceed the equivalent of $100 \mathrm{ml}(0.05 \mathrm{ml}$ per worm per day $)$ [1].

These parasites have very different life cycles, but in each instance, their gastrointestinal developmental stage (often adult worms) has been clearly identified as one of the targets of immunity. Several important reviews on immunity in parasitic diseases have appeared in recent years [2-8] and the present one will attempt to classify the data in a rational, nonhistorical way.

\section{Results of the Host-Worm Interaction}

\section{Lesions and Fate of the Worms}

Adult worms of Nippostrongylus brasiliensis live in the anterior third of the small intestine where females lay eggs from day 6 after a primary infection. On day 10 p.i., worms show biochemical and morphological changes or lesions [reviewed in ref. 9]. There- after, between day 10 and day 14 , dramatic events take place: eggs are no longer produced, the worm burden is eliminated, with the females being eliminated earlier and faster than males and only a small number of worms remaining in the intestine for a long time $[10,11]$. Similar events are observed with some variations in mice infected with Trichinella spiralis [12, 13], in rats infected with Strongyloides ratti $[14,15]$ and in rats or mice infected with the cestode Hymenolepis diminuta [16]. In these examples, the expulsion occurs during a primary infection; it may also occur when a second homologous population of larvae is superimposed on an already existing one as in the classical 'selfcure' phenomenon, which was described in sheep infected with H. contortus by Gordon [17].

Subsequent reinfections lead generally to an acceleration of these events resulting in a very rapid, specific expulsion and in the protection of the host. Both in rats infected with $T$. spiralis [18] and in rats infected with $N$. brasiliensis [19], mucosal trapping is an early event in this rapid expulsion.

Local immunopathological reactions of the host during infection will be mentioned in the next section. 
Specific and Nonspecific Mediators of the Reactions

\section{Role of Lymphocytes}

Adoptive immunization of normal or irradiated hosts was successfully achieved in $N$. brasiliensis $[20,21]$ and $S$. ratti [22] infections in rats, in Trichuris muris [23] and T. spiralis $[24,25]$ infections in mice, and in Trichostrongylus colubriformis [25] infections in guinea pigs. The transferred cells came from either the thoracic duct lymph $[20,21,25]$ or the mesenteric lymph node $[20,21,24,26]$. When recipients were treated with high levels of irradiation and mesenteric lymph node cells were transferred, another bone marrow-derived cell was required both for the restoration of the expulsion of $N$. brasiliensis [27] and $T$. spiralis [28].

When fractionated immune lymphocytes were transferred from hosts during a primary infection, the effector cells which caused worm expulsion were found in the T cell population $[20,29,30]$. T cells from immune rats caused expulsion of damaged $N$. brasiliensis worms implanted in irradiated recipients [20]. This suggested that they were sensitized to worm antigens. On the other hand, B cells from $T$. spiralis-infected mice were able to reduce worm fertility in irradiated mice (when complemented with normal $\mathrm{T}$ cells), but were unable to expel the worm population [30]. When the fractionated cells were obtained from hyperimmune hosts, $T$ cells were always the major effector cells, but a significant protection was conferred by $\mathrm{sIg}^{+}$or $\mathrm{B}$ cells [25, 29]. Hypothymic animals were generally unable to expel their worm burden, but an injection of $T$ cells enabled them to achieve expulsion [4].

The participation of $T$ cells in protective immunity is further supported by the suc- cessful transfer of protection by the corresponding transfer factors in sheep infected with $T$. colubriformis, Ostertagia circumcinta [31], Trichostrongylus axei [32], or $H$. contortus [33]. Several if not all pathological reactions of the hosts were also under some control of $T$ cells: villous atrophy and crypt hyperplasia [34], intestinal goblet cell differentiation [35], and intestinal mast cell and globule leukocyte hyperplasia $[36,37]$.

\section{Role of Antibodies}

It has been known for a long time that $N$. brasiliensis-infected rats can be passively protected by injections of serum from hyperimmunized animals [11]. Such experiments were repeated by several authors and can be summarized as follows: The serum can be injected until day 4 after infection [38, 39]; serum without reagins [40] or deprived of $\operatorname{IgE}$ antibodies by immunoabsorption on adult worms [38] confers the protection; hyperimmune serum is more protective than serum from rats infected once, but significant protection occurs with serum collected on day 6 after primary infection [39]; there is a lag between injection of serum and expulsion $[38,39]$. These antibodies were able to reproduce in vitro some of the lesions the worm suffered in vivo [41, 42]. Similarly, serum (IgM) and secretory (IgA) antibodies of infected animals (minipigs, rats and mice) exerted an inhibitory effect upon the release of newborn larvae during in vitro maintenance of $T$. spiralis females [43]. Concerning the mucus trapping of $T$. spiralis during the rapid expulsion in immunized hosts [19], both a specific heat-stable factor, probably antibody, and a nonspecific heat-labile factor promoted mucus trapping of worms in vitro.

If immune sera were generally employed for passive protection, it was also shown in 
several systems [44-46] that the rise in mucosal $\mathrm{IgA}$ antibodies was more closely associated with the evolution of protection than the production of serum antibodies.

A transfer of immunity from mothers to offspring has been observed [47] and was tentatively related to colostrum and milk antibodies. However, such transfer must be reexamined due to the new data on the transfer of 'transplanted' lymphocytes through the intestinal epithelium of adult rats [48]. In contrast, $N$. brasiliensis-infected mice which lacked the potential of antibody production after a neonatal anti- $\mu$ treatment were able to expel their worms and it seemed that in this system anti-worm antibodies are not required in the expulsion [49].

\section{Role of Nonlymphoid Effector Cells and}

\section{of Nonspecific Mediators}

The production of a local anaphylaxis in rats passively immunized against $N$. brasiliensis with immune serum produced an accelerated expulsion of worms as compared to rats which were only passively immunized [50]. This stresses the importance of mast cell degranulation and of vasoactive amines which increase the mucosal permeability. Furthermore, repeated injections of antimast cell antiserum inhibited the self-cure [51].

$\mathrm{W} / \mathrm{W}^{\mathrm{v}}$ anemic mice which did not accumulate mucosal mast cells in response to $N$. brasiliensis eliminated a first infection more slowly than did their normal littermates, but were just as refractory to subsequent infections as controls [52].

Variations in the gastric or intestinal mucosal histamine or 5-hydroxytryptamine content, which may be correlated with worm expulsion, were observed in different systems [53-57]. Daily injections of inhibitors of histamine and 5-hydroxytryptamine in rats in- fected with $N$. brasiliensis inhibited worm loss but did not stop the decrease in egg production occurring in untreated rats [58]. This may indicate that antibody damage is still active in treated rats. In contrast, Keller and Ogilvie [59] concluded from other experiments that there was no direct evidence to link amine release with worm expulsion.

Prostaglandins and especially prostaglan. din $E_{1}$ increased also in the jejunal site of $N$. brasiliensis-infected rats; their level increased more rapidly upon reinfection [60] and they were able to damage worms in vitro [61]. However, other studies [52] did not provide support for a direct role of prostaglandins in worm expulsion.

\section{Genetic Factors}

A genetic control of immunity has been demonstrated in several host-parasite systems. This subject was recently reviewed by Wakelin [2] and will not be treated here.

\section{Unresponsiveness}

In 1962 Manton et al. [63] reported that lambs 4 months of age failed to mount a protective response against $H$. contortus. Since a transfer factor was acting when injected in such lambs [33] and since 1-month-old lambs were able to produce hemagglutinating antibodies [7], it might well be that one or several subpopulations of $\mathrm{T}$ cells are inefficient physically (absent or nonmature) or functionally (tolerated).

When young rats are infected with $N$. brasiliensis before 21 days of age, the self-cure phenomenon is either greatly reduced or even suppressed [64]. The young rats produce protective antibodies in their serum and the worms are subjected to lesions [42]. The expulsion takes place if the young rats are given mesenteric lymph node cells from adult 
rats, but their own lymphocytes are unable to transfer protection [65]. The cause of impairment may be the result of tolerance or a delay in the ontogeny of the cellular immune response.

The self-cure is also inhibited in lactating females. Mesenteric lymph node cells from these females caused rejection of the worms in multiparous recipients but were less effective in lactating recipients [66]. It seemed that prolactin affected the activity of lymphocytes in the lactating females [67].

\section{Conclusion -}

\section{Mechanisms of Worm Expulsion}

Classically three main hypotheses were put forward to include all these facts and to provide a unifying explanation of worm expulsion in various systems.

(1) The 'leak lesion' hypothesis [11]: A local anaphylactic reaction increases the mucosal permeability and allows specific antiworm antibodies to reach the worms and to act directly on them to cause their expulsion.

(2) The two-step hypothesis [40]: The first step is immunologically specific and antibodies (IgG and perhaps $\operatorname{IgA}$ antibodies) damage the worms which become susceptible to step 2. The second step does not require antibody but components which are associated with inflammation. Lymphokines or amines released from mast cells interfere with the metabolism of damaged worms thereby causing their expulsion. These two hypotheses resulied from studies on rats infected with $N$. brasiliensis.

(3) The inflammation hypothesis [68]: The first event is a specific delayed type hypersensitivity reaction which results in tis- sue injury and is accompanied by a nonspecific inflammatory process that leads to migration and homing of lymphoblasts to the intestine [68] and to tissue changes which are unfavorable to the maintenance of the worms.

In fact there are at least two types of expulsion: that which follows a first infection and that which is operating very rapidly (within hours) on already damaged larvae of $N$. brasiliensis $[70,71]$ or on intact worms of T. spiralis in immunized animals. In this latter instance, it seems that the challenging worms, after interaction of their antigens with IgE antibodies on mucosal mast cells, cause a release of mucus from intestinal goblet cells as described by Lake et al. [72] and an increased mucosal permeability. Interaction between mucus and antibodies or nonspecific factors results in mucus trapping of the parasites $[18,19]$ whereas other mediators from mast cells (histamine, vasoactive intestinal peptide) [73] may induce change in gut peristalsis and thereby worm expulsion. This chain of steps may well operate in the self-cure reaction in $H$. contortus-infected sheep if molting fluids are the sensitizing antigens [6].

The mechanisms of expulsion in the nonimmunized host are less clear. If a unique set of reactions explains all expulsions with variations due to the parasite, the species or the strain of the host and the experimental design, the following points may emerge: (1) The worms are nearly always damaged before they are expelled; (2) some of the damage is due to antibodies; (3) antibody damage does not automatically lead to expulsion and is not required to initiate the component which expels damaged worms; (4) the expulsion is mediated by $T$ cells which act either as helper cells or as lymphokines releasing sensitized 
cells, leading to inflammatory reaction and modification of the worm microenvironment. In this schema, mast cells and soluble mediators will be part of the inflammatory process. Certainly, several reactions are working in parallel ways and when one component of the chain is inactive, another is able to somewhat replace it, leading to the same final result. The clue to the puzzle lies probably in the active interaction between soluble mediators of immunity or/and inflammation, the intestinal mucus-secreting apparatus, and the modified gastrointestinal activity, and further work is needed for understanding these interactions. However, both the primary expulsion and the rapid expulsion mechanisms which are proposed here might explain interactive expulsion of unrelated parasites upon a homologous challenge [74-77].

\section{References}

I Dargie, J.D.: Ovine haemonchosis. Pathogenesis; in Urquhart, Armour, Helminth diseases of cattle, sheep and horses in Europe, pp. 63-71 (MacLehose, University Press, Glasgow 1973).

2 Wakelin, D.: Genetic control of susceptibility and resistance to parasitic infection; in Lumsden, Muller, Baker, Adv. parasitol., vol. 16, pp. 217308 (Academic Press, London 1978).

3 Wakelin, D.: Immunity to intestinal parasites. Nature, Lond. 273: 617-620 (1978).

4 Mitchell, G.F.: Responses to infection with metazoan and protozoan parasites in mice. Adv. Immunol. 28: 451-511 (1979).

5 Mitchell, G.F.: Effector cells, molecules and mechanisms in host-protective immunity to parasites. Immunology 38: 209-223 (1979).

6 Soulsby, E.J.L.: The immune system and helminth infection in domestic species; in Brandly, Cornelius, Adv. vet. Sci. comp. Med., vol. 23, pp. 71102 (Academic Press, New York 1979).

7 Soulsby, E.J.L.: Host reaction and non-reaction to parasitic organisms; in Gaafar, Pathology of parasitic diseases, pp. 243-267 (Purdue University Press, Ind. 1971).

8 Pery, P.; Luffau, G.: Antigens of helminths; in Sela, The antigens, vol. 5, pp. 83-172 (Academic Press, New York 1979).

9 Lumley, A.M.; Lee, D.L.: Changes in nematodes during development of immunity to these nematodes in their hosis: proteolytic enzymes; in Van den Bossche. The host invader interplay, pp. 443459 (Elsevier/North Holland Biomedical Press, Amsterdam 1980).

10 Ogilvie, B.M.: Role of adult worms in immunity of rats to Nippostrongylus brasiliensis. Parasitology 55: 325-335 (1965).

11 Mulligan, W.; Urquhart, G.M.; Jennings, F.W.; Neilson, J.T.M.: Immunological studies on Nippostrongylus brasiliensis infection in the rat. The self-cure phenomenon. Expl Parasit. 16: 341-347 (1965).

12 Love, R.J.; Ogilvie, B.M.; McLaren, D.J.: The immune mechanism which expels the intestinal stage of Trichinella spiralis from rats. Immunology 30: 7-14 (1976).

13 Kennedy, M.W.; Wakelin, D.; Wilson, M.M.: Transplantation of adult Trichinella spiralis between hosis: worm survival and immunological characteristics of the host-parasite relationship. Parasitology 78: 121-130 (1979).

14 Moqbel, R.; McLaren, D.J.: Strongyloides ratti: structural and functional characteristics of normal and immune-damaged worms. Expl Parasit. 49: 139-152 (1980).

15 Moqbel, R.; MeLaren, D.J.; Wakelin, D.: Strongyloides ratti: reversibility of immune damage to adult worms. Expl Parasit. 49: 153-166 (1980).

16 Hopkins, C.A.: Immunity and Hymenolepis diminuta; in Arai, The biology of the tapeworm, $\mathrm{Hy}$ menolopis diminuta, pp. 551-614 (Academic Press, New York 1980).

17 Gordon, H. McL.: The epidemiology of parasitic diseases with special reference to studies with nematode parasites of sheep. Aust. vet. J. 24: 17-45 (1948).

18 Miller, H.R.P.: Juntley, J.F.; Wallace, G.R.: Immune exclusion and mucus trapping during the rapid expulsion of Nippostrongylus brasiliensis from primed rats. Immunology 44: 419-429 (1981).

19 Lee, G.B.; Ogilvie B.M.: The mucus layer in intes- 
tinal nematode infections; in Ogra, Bienenstock, The mucosal immune system in health and disease, pp. 175-186 (Ross Laboratories, Columbus, Ohio 1981).

20 Ogilvie B.M.; Love, R.J.; Jarra, W.; Brown, K.N.: Nippostrongylus brasiliensis infection in rats. The cellular requirement for worm expulsion. Immunology 3: 521-527 (1977).

21 Nawa, Y.; Miller, H.R.P.: Protection against Nippostrongylus brasiliensis by adaptive immunization with immune thoracic duct lymphocytes. Cell. Immunol. 37: 51-60 (1978).

22 Moqbel, R.; Wakelin, D.: Immunity to Strongyloides ratti in rats. 1. Adoptive transfer with mesenteric lymph node cells. Parasite Immunol. 3: 181-189 (1981).

23 Wakelin, D.: Immune expulsion of Trichuris muris from mice during a primary infection: analysis of the components involved. Parasitology 70: 397405 (1975).

24 Wakelin, D.; Wilson, M.M.: Transfer of immunity to Trichinella spiralis in the mouse with mesenteric lymph node cells. Time of appearance of effective cells in donors and expression of immunity in recipients. Parasitology 74: 215-224 (1977).

25 Crum, E.D.; Despommier, D.D.; McGregor, D.D: Immunity to Trichinella spiralis. I. Transfer of resistance by two classes of lymphocytes. Immunology 33: 787-795 (1977).

26 Adams, D.B.; Rothwell, T.L.W.: The role of lymphocytes in immunological memory for resistance to infection by Trichostrongylus colubriformis in guinea pigs. Ceil. Immunol. 55: 1-11 (1980).

27 Kelly, J.D.; Dineen, J.K.; Love, R.J.: Expulsion of Nippostrongylus brasiliensis from the intestine of rats. Evidence of a third component in the rejection mechanism. Int. Archs Allergy appl. Immun. 45: 767-779 (1973).

28 Wakelin, D.; Wilson, M.M.: Evidence for the involvement of a bone marrow-derived cell population in the immune expulsion of Trichinella spiralis. Parasitology 74: 225-234 (1977).

29 Nawa, Y.; Parish, C.R.; Miller, H.R.P.: The protective capacities of fractionated immune thoracic duct lymphocytes against Nippostrongylus brasiliensis. Cell. Immunol. 37: 41-50 (1978).

30 Wakelin, D.; Wilson, M.M.: Immunity to Trichinella spiralis in irradiated mice. Int. J. Parasitol. 10: $37-41$ (1980).
31 Ross, J.G.; Halliday, W.G.: Investigations of 'transfer factor' activity in immunity to Ostertagia circumcincta and Trichostrongylus colubriformis infections in sheep. Int. J. Parasitol. 9: 281-284 (1979).

32 Ross, J.G.; Halliday, W.G.: Investigations of 'transfer factor' activity in the transfer of immunity to Trichostrongylus axei infections in sheep. Res. vet. Sci. 26: $41-46$ (1979).

33 Ross, J.G.; Duncan, J.L.; Halliday, W.G.: Investigation of Haemonchus contortus infections in sheep. Comparison of irradiated larvae and transfer factor treatment. Res. vet. Sci. 27: 258-259 (1978).

34 Manson-Smith, D.F.; Bruce, R.G.; Parrott, D.M.V.: Villous atrophy and expulsion of intestinal Trichinella spiralis are mediated by $\mathrm{T}$ cells. Cell. Immunol. 47: 285-292 (1979).

35 Miller, H.R.P.; Nawa, Y.: Nippostrongylus brasiliensis: intestinal goblet-cell response in adoptively immunized rats. Expl Parasit. 47: 81-90 (1979).

36 Nawa, Y.; Miller, H.R.P.: Adoptive transfer in the instestinal mast cell-response in rats infected with Nippostrongylus brasiliensis. Cell. Immunol. 42: 225-229 (1979).

37 Mayrhoffer, G.: The nature of the thymus dependency or mucosal mast cells. I. An adaptive secondary response to challenge with Nippostrongylus brasiliensis. Cell. Immunol. 47: 304-311 (1979).

38 Luffau, G.: Propriétés biologiques du sérum hyperimmun provenant de rats infestés par Nippostrongylus brasiliensis. Ann. Rec. Veter. 3: 319-346 (1972).

39 Miller, H.R.p.: Expulsion of Nippostrongylus brasiliensis from rats protected with serum. I. The efficacy of sera from singly and multiply infected donors related to time of administration and volume of serum injected. Immunology $40: 325-334$ (1980).

40 Jones, V.E.; Ogilvie, B.M.: Protective immunity to Nippostrongrlus brasiliensis: sequence of events which expels worms from the rat intestine. Immunology 20: 549-561 (1971).

41 Jones, V.E.; Ogilvie, B.M.: Protective immunity to Nippostrongllus brasiliensis in the rat. III. Modulation of worm acetylcholinesterase by antibodies. Immunology 22: 119-129 (1972).

42 Love, R.J.; Ogilvie, B.M.; McLaren, D.J.: Nippostrongylus brasiliensis: further properties of antibody-damaged worms and induction of compara- 
ble damage by maintaining worms in vitro. Parasitology 71: 275-283 (1975).

43 Vernes, J.A.; Bout, D.; Biguet, J.: Trichinella spiralis: facteurs immunitaires inhibiteurs de la production de larves. II. Première analyse in vitro des facteurs humoraux et sécrétoires actifs chez la Souris, le Rat, et le Miniporc infestés ou immunisés. Expl Parasit. 45: 42-54 (1978).

44 Poulain, J.; Luffau, G.; Pery, P.: Nippostrongylus brasiliensis in the rat: immune response in serum and intestinal secretions. Ann. Immunol., Paris C 127: 21 5-224 (1976).

45 Sinski, E.; Holmes, P.H.: Nippostrongylus brasiliensis: systemic and local IgA and IgG immunoglobulin responses in parasitized rats. Expl Parasit. 43: 382-389 (1977).

46 Smith, W.D.: Anti-larval antibodies in the serum and abomasal mucus of sheep hyperinfected with Haemonchus contortus. Res. vet. Sci. 22: 334-338 (1977).

47 Greenberg, Z:: Passive transfer of immunity to N. brasiliensis from mother rats to offspring. J. Parasit. 57: 685-687 (1971).

48 Seelig, L.; Billingham, R.E.: Capacity of 'transplanted' lymphocytes to traverse the intestinal epithelium of adult rats. Transplantation 32: 308-314 (1981).

49 Jacobson, R.H.; Reed, N.D.; Manning, D.D.: Expulsion of Nippostrongylus brasiliensis from mice lacking antibody production potential. Immunology 32: 867-873 (1977).

50 Barth, E.E.; Jarrett, W.F.H.; Urquhart, G.M.: Siudies on the mechanism of self-cure reaction in rats infected with Nippostrongylus brasiliensis. Immunology 10: 459-464 (1966).

51 Hogarth-Scott, R.S.; Bingley, J.B.: Prolongation and enhancement of Nippostrongylus infection in the laboratory rat by a heterologous antiserum to rat peritoneal cells. A possible role for pharmacologically-active cells in immunity. Immunology 21: 87-99 (1971).

52 Crowle, P.K.; Reed, N.D.: Rejection of the intestinal parasite Nippostrongy/us brasiliensis by mast cell-deficient $W / W^{v}$ anemic mice. Infect. Immunity 33: 54-58 (1981).

53 Wells, P.D.: Mast cell, eosinophil and histamine levels in Nippostrongylus brasiliensis infected rats. Parasitology 12: 82-101 (1962).

54 Murray, M.; Miller, H.R.P.; Sanford, J.; Jarrett, W.F.H.: 5-Hydroxytryptamine in intestinal im- munological reactions. Its relationship to mast cell activity and worm expulsion in rats infected with Nippostrongylus brasiliensis. Int. Archs Allergy appl. Immun. 40: 236-247 (1971).

55 Jones, W.O.; Rothwell, T.L.W.; Adams, D.B.: Studies on the role of histamine and 5-hydroxytryptamine in immunity against the nematode Trickostrongylus colubriformis. V. Changes in amine levels in the intestine following infection of guinea pigs of different immune status. Int. Archs Allergy appl. Immun. 57: 48-56 (1978).

56 Befus, A.D.; Johnston, N.; Bienenstock, J.: Nippostrongylus brasiliensis: mast cells and histamine levels in tissues of infected and normal rats. Expl Parasit. 48: 1-8 (1979).

57 Luffau, G.; Carrat, C.; Charley-Poulain, J.; Pery, P.; Sarr, J.: Réaction d'hypersensibilité immédiate dans la muqueuse stomacale chez le mouton infesté par Haemonchus contortus. Phénomène d'autostérilisation. Commun. Soc. Fr. Parasit. (1981).

58 Murray, M.; Smith, W.D.; Waddell, A.H.; Jarrett, W.F.H.: Nippostrongylus brasiliensis: histamine and 5-hydroxytryptamine inhibition and worm expulsion. Expl Parasit. 30: 58-63 (1971).

59 Keller, R.; Ogilvie, B.M.: The effects of drugs on worm expulsion in the Nippostrongylus brasiliensis infected rat: a discussion of interpretation of drug action. Parasitology 64: 217-228 (1972).

60 Dineen, J.K.; Kelly, J.D.: Levels of prostaglandins in the small intestine of rat during primary and secondary infection with Nippostrongylus brasiliensis. Int. Archs Allergy appl. Immun. 51: 429440 (1976).

61 Richards, A.J.; Bryant, C.; Kelly, J.D.; Windon, R.G.; Dineen, J.K.: The metabolic lesion in Nippostrongylus brasiliensis induced by prostaglandin $E_{1}$ in vitro. Int. J. Parasit. 7: 153-158 (1977).

62 Kassai, T.; Redl, P.; Jecsai, G.; Balla, E.; Harangozo, E.: Studies on the involvement of prostaglandins and their precursors in the rejection of Nippostrongylus brasiliensis from rat. Int. J. Parasitol. 10: 115-120 (1980).

63 Manton, V.J.A.; Peacock, R.; Poynter, D.; Silverman, P.H.; Terry, R.J.: The influence of age on naturally acquired resistance to Haemonchus contortus in lambs. Res. vet. Sci. 3: 308-314 (1962).

64 Dineen, J.L.; Kelly, J.D.: Immunological unresponsiveness of neonatal rats to infection with Nippostrongylus brasiliensis. The competence of 
neonatal lymphoid cells in worm expulsion. Immunology 25: 141-150 (1973).

65 Ogilvie, B.M.; Hockley, D.J.: Effects of immunity on Nippostrongylus adult worms: reversible and irreversible changes in infectivity, reproduction and morphology. J. Parasit. 54: 1073-1084 (1968).

66 Dineen, J.K.; Kelly, J.D.: The suppression of rejection of Nippostrongylus brasiliensis in lactating rats: the nature of immunological defect. Immunology 22: 1-12 (1972).

67 Kelly, J.D.; Dineen, J.K.: The suppression of rejection of Nippostrongylus brasiliensis in Lewis strain rats treated with ovine prolactin. The site of the immunological defect. Immunology 24: 551-558 (1973).

68 Larsh, J.E.; Race, G.J.: Allergic inflammation as a hypothesis for the expulsion of worms from tissues: a review. Expl Parasit. 37: 251-266 (1975).

69 Rose, M.L.; Parrott, D.M.V.; Bruce, R.G.: Migration of lymphoblasts to the small intestine. 1 . Effect of Trichinella spiralis infection on the migration of mesenteric lymphoblasts ans mesenteric $\mathrm{T}$ lymphoblasts in syngeneic mice. Immunology 31: 723-730 (1976).

70 Love, R.J.; Kelly, J.D.; Kineen, J.K.: Nippostrongylus brasiliensis: effects of immunity on the preintestinal and intestinal larval stages of the parasite. Int. J. Parasitol. 4: 183-191 (1974).

71 Luffau, G.; Pery, P.; Petit, A.; Poulain, J.: Rôle de la sensibilisation des larves pulmonaires de Nippostrongylus brasiliensis dans le phénomène d'autostérilisation. Ann. Immunol., Paris C 127: 104 (1976).
72 Lake, A.M.; Bloch, K.J.; Sinclair, K.J.; Walker, W.A.: Anaphylactic release of intestinal goblet cell mucus. Immunology 39: 173-178 (1980).

73 Castro, G.A.: Regulation of pathogenesis in disease causes by gastro-intestinal parasites; in Van den Bossche, The host invader interplay, pp. 457467 (Elsevier/North Holland Biomedical Press, Amsterdam 1980).

74 Kazacos, K.R.; Thorson, R.E.: Cross-resistance between Nippostrongylus brasiliensis and Strongyloides ratti in rats. J. Parasit. 61: 525-529 (1975).

75 Bruce, R.G.; Wakelin, D.: Immunological interactions between Trichinella spiralis and Trichuris muris in the intestine of the mouse. Parasitology 74: 163-173 (1977).

76 Moqbel, R.; Wakelin, D.: Trichinella spiralis and Strongyloides ratti: immune interaction in adult rats. Expl Parasit. 47: 65-72 (1979).

77 Kennedy, M.W.: Immunologically mediated, nonspecific interactions between the intestinal phases of Trichinella spiralis and Nippostrongylus brasiliensis in the mouse. Parasitology 80: 61-72 (1980).

Pierre Pery, Station de Recherches de Virologie et d'Immunologie, INRA, F-78850 Thiverval-Grignon (France) 